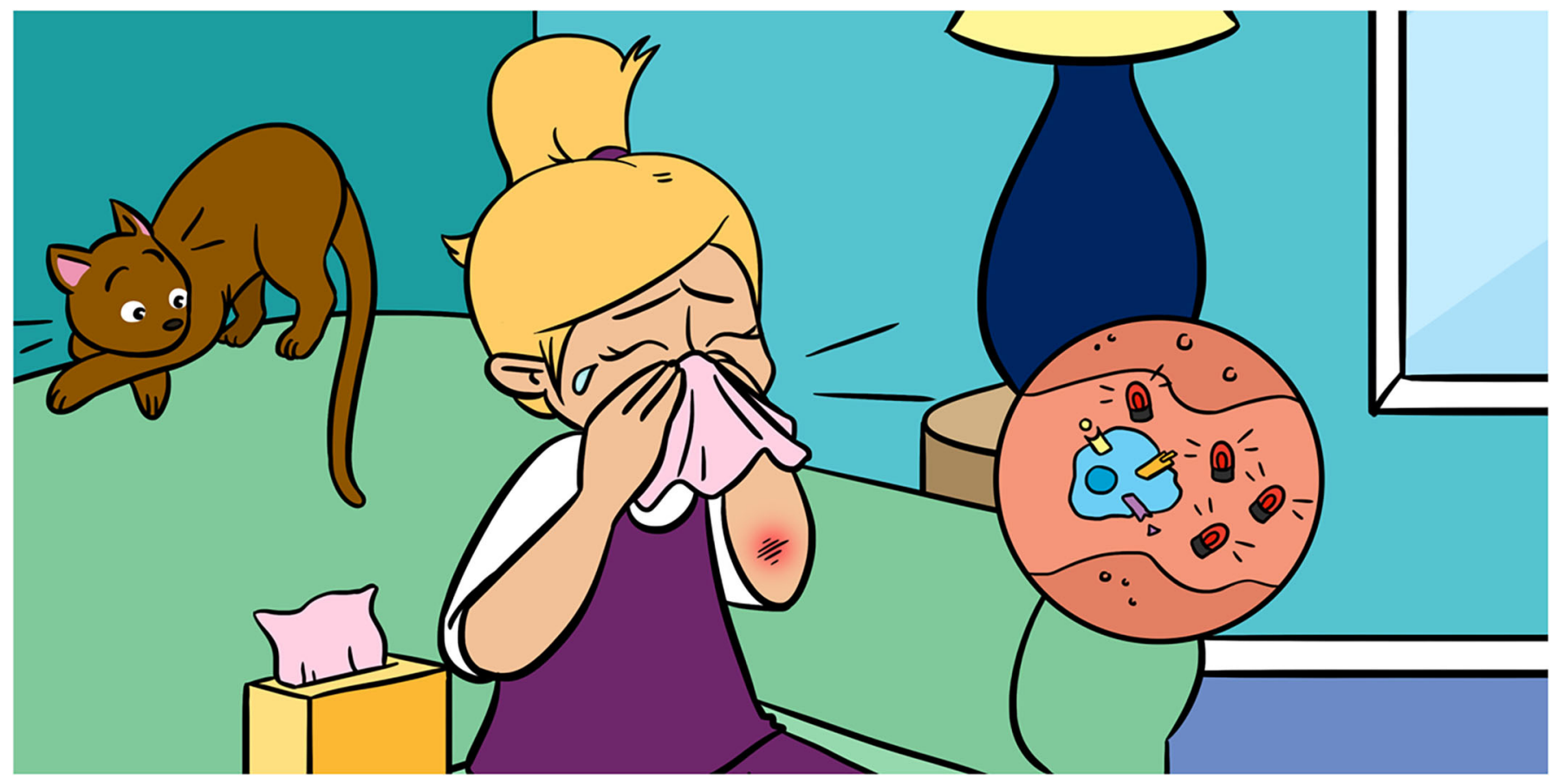

\title{
HOW THE INNATE IMMUNE SYSTEM FIGHTS FOR YOUR HEALTH
}

\section{Mieke C. Louwe ${ }^{1 *}$ and Pål Aukrust ${ }^{1,2,3}$}

${ }^{1}$ Research Institute of Internal Medicine, Oslo University Hospital, Oslo, Norway

${ }^{2}$ Faculty of Medicine, University of Oslo, Oslo, Norway

${ }^{3}$ Section of Clinical Immunology and Infectious Diseases, Oslo University Hospital Rikshospitalet, Oslo, Norway

YOUNG REVIEWERS:

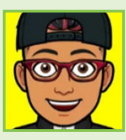

AARUSH

AGE: 12

VIBHAV

AGE: 9

\section{IMMUNE SYSTEM}

A complex system of cells and organs that protects the body from harmful microbes. The innate immune system works immediately, while the adaptive immune system takes a few days to

start working
When your body encounters intruders like viruses, bacteria, fungi, or parasites, this invasion triggers a complex and amazing process called the immune response. Activation of the body's immune system is necessary to fight off these intruders, but it must also distinguish them from the body's own healthy tissues. The goal of the immune response is to keep the body healthy. The earliest responses that occur to protect the body from invading organisms is called the innate immune response. In this article, we explain the components of the innate immune system and how this system helps to keep the body safe from dangerous invaders.

\section{QUICK VS. SLOW IMMUNE RESPONSES}

The immune system has received a lot of media attention lately because of the current COVID-19 pandemic. Terms such as immunity and vaccination are now part of our common language. Most of the 
INNATE IMMUNE SYSTEM

Part of the immune system responding the first and instantly to protect the body from invading organisms.

\section{PATTERN}

RECOGNITION

\section{RECEPTORS}

Molecules on immune cells that can detect "non-self" structures present on the surfaces of microbes. attention is focused on one specific part of the immune system, called the adaptive immune system. "Adaptive" means able to change, or adapt, to new situations. Thus, adaptive immunity develops step by step, with every new infection. The advantage of the adaptive immune system is that it has memory-it can remember intruders that it has seen before. If the same microbe tries to invade the body again, adaptive immune cells can respond more quickly and strongly. The drawback of the adaptive immune system is that upon a first infection, the initial response takes a couple of days to get started. In the case of a severe infection, every minute counts! Even a few days of waiting time can be too long and may result in death. Luckily, the adaptive immune system has a partner: the innate immune system, which responds instantly upon microbial invasion.

\section{FIRST LINE OF DEFENSE: THE FORTRESS}

The basic protection mechanism of the immune system is amazingly simple: it distinguishes between cells of your own body, or "self," and foreign things, or "non-self." Parasites, viruses, and bacteria are all intruders seen by the immune system as "non-self." Since many of these intruders can be dangerous, they must be eliminated as quickly as possible.

The innate immune system does not care if the invader is a bacterium, parasite, fungi, or virus, it simply wants to stop and/or kill any intruder. It has several lines of defense to slow down or prevent intruders to enter the body. You might be surprised to know that you touch the largest physical barrier of the innate immune system every day-your skin. Like a fortress, the skin protects us against any invader that wants to enter the body. Intact skin is hard to penetrate. The natural openings in the skin have their own defensive weapons. Think about the tiny hairs inside the ears and nose that can deter potential invaders, or mucus, a sticky fluid that traps microbes. You have probably seen this defense mechanism at work when you have a cold: you experience increased mucus production and need to blow your nose or clear your throat often. In the eyes, tears wash away microbes. Tears themselves are full of substances that can attack and break down bacteria. Microbes that try to enter our bodies via the foods we eat face digestive enzymes in the mouth and strong acids in the stomach and intestines.

\section{SECOND LINE OF DEFENSE: BOOBY TRAPS}

If microbes manage to get through the body's physical barriers, there are some booby-traps built into the body as an internal defense. A key element in this second defensive line is the recognition of common structures on the surfaces of invaders. Bacteria, viruses, and parasites have patterns on their cells that are not found in a healthy body. Molecules called pattern recognition receptors on the cells 
Figure 1

Pattern

recognition receptors on immune cells can recognize specific structures from microbes. When microbial structures bind to pattern recognition receptors, the body's "alarm system" is triggered, activating defense and repair programs that eliminate the invader.

\section{INFLAMMATORY}

\section{MEDIATORS}

Substances that act on cells and/or blood vessels and promotes inflammation.

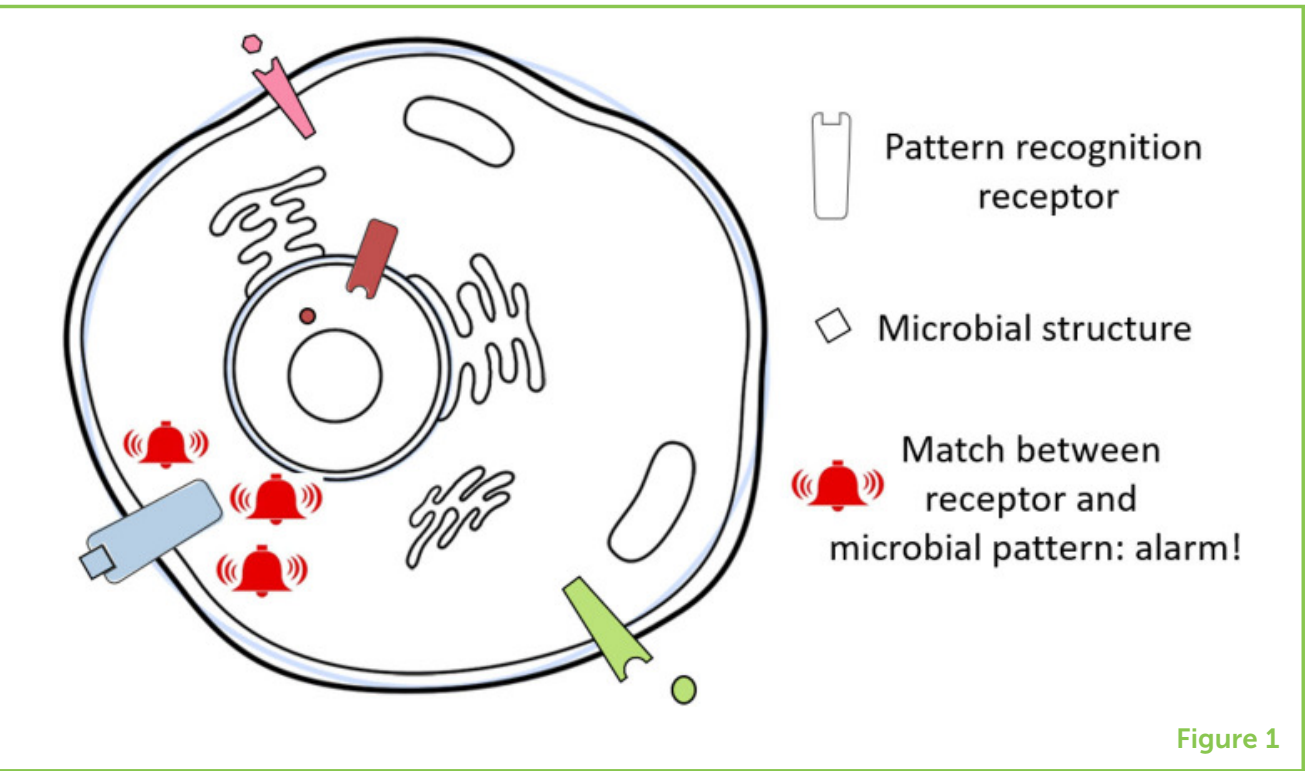

of the innate immune system can bind to these foreign structures. This works kind of like a shape sorter: only a certain pattern fits and activates the receptor (Figure 1) [1]. Immune cells with pattern recognition receptors are strategically found in all possible locations where intruders might enter the body, hide, and reproduce. Once a microbial intruder activates a pattern recognition receptor, alarm bells go off in the body, which activate defense and repair programs to help the body get rid of the microbes as quickly as possible.

\section{THIRD LINE OF DEFENSE: INFLAMMATION}

When pattern recognition receptors on immune cells recognize an intruder, one of the "alarm" responses is the release of substances called inflammatory mediators, which cause inflammation. Inflammation is a normal response to infection or to damaged or dying cells in the body. The affected area becomes red, painful, hot and swollen and often reduces your mobility, for example with an infected foot. The goal of inflammation is to keep the infection in one location, to prevent it from spreading and infecting other parts of the body. To achieve this, the intruder must be eliminated quickly [2]. Inflammatory mediators can also cause pain, making you aware that something is wrong. Pain tells you to protect the injured/infected part of your body and to take it easy. Another protection mechanism activated by inflammatory mediators is the widening of small blood vessels in the infected area. This result in increased blood flow, and the area turns red and becomes hot and swollen. Widening of the blood vessels allows more immune cells (described below) to quickly travel via the blood to the trouble spot. This helps to eliminate the infection.

Fever, or a rise in body temperature, can occur with many infections. High body temperature helps the body to deal with the infection. 


\section{Figure 2}

The skin, mucus, tears, and tiny hairs in the nose and ears help to prevent microbial invaders from entering the body. If microbes get through these defenses, the cells of the innate immune system will attack them. Neutrophils arrive first and can produce fibers to trap microbes. Macrophages phagocytose a lot of microbes. Dendritic cells activate the adaptive immune system by showing it pieces of the invader.

\section{NEUTROPHIL}

Most common type of white blood cell, arrives first at the infection. Performs the initial scouting of the area, eats microbes, and produce cytokines.

\section{PHAGOCYTOSIS}

Cell eating, a process where a cell ingests and digests microbes and damaged or dying cells.

\section{CYTOKINE}

Messenger produced by cells, crucial for communication between cells.

\section{MACROPHAGE}

Type of white blood cell that hunts and eats microbes and damaged cells.

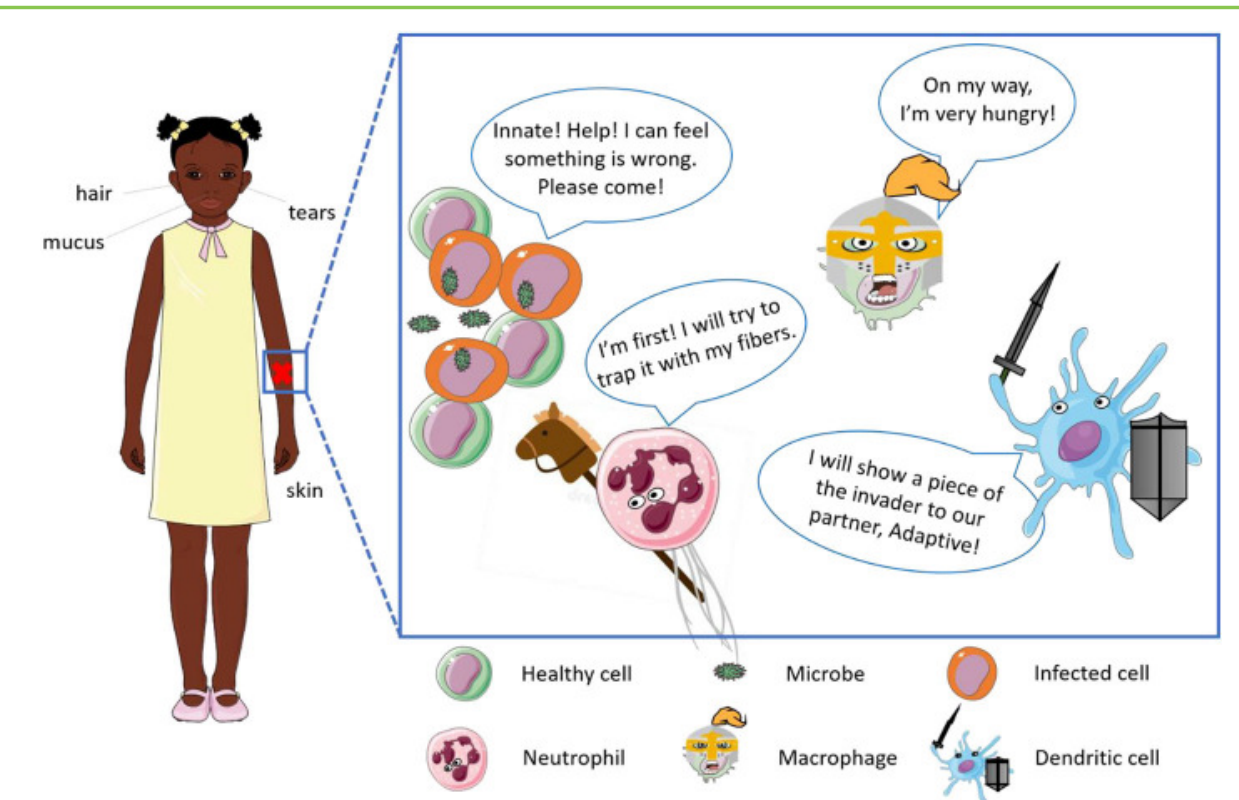

Figure 2

First, an increase in temperature can kill some microbes. Bacteria, for example, hate high temperatures. Second, increased temperature stimulates the body's repair processes, because warmth increases blood flow, which results in more oxygen and nutrients traveling to the infected body part. Last, fever encourages us to rest, which is important for recovery. So, the next time you have a fever, remember it is your innate immune system fighting for your health!

\section{MASTER OF DEFENSE: INNATE IMMUNE CELLS}

Cells of the immune system, also known as white blood cells, are crucial for reducing inflammation and eliminating infection (Figure 2) [3]. We will discuss three important types of innate immune cells: neutrophils, macrophages, and dendritic cells.

The frontline warriors that arrive within minutes after the warning signal are cells called neutrophils. Neutrophils are the most common type of white blood cell. Neutrophils can produce fibers that form nets, almost like a spider web, which can trap bacteria. Neutrophils perform the initial scouting of the infected area, they phagocytose (eat) microbes, and they produce substances called cytokines. Cytokines are like the text messages of the immune system, providing communication between immune cells and between the immune system and the rest of the body. Cytokines tell immune cells where to go, and they tell the immune system which types of immune cells are needed to fight that specific intruder.

Macrophages arrive shortly after neutrophils but stay in the tissues longer. Some macrophages are normally present in body tissues, 


\section{DENDRITIC CELL}

Type of white blood cell that presents pieces of microbes to the adaptive immune system. Serves as a bridge between the innate and adaptive immune system. waiting to protect us from attack. The main task of macrophages is to phagocytose as many invaders as possible. Macrophages have a huge phagocytic capacity, so they can eat a lot more than neutrophils! Macrophages hunt for microbes and damaged cells, almost like a Pac-Man.

Last, dendritic cells are present in tissues that contact the outside of the body, mainly in the skin, but also in the nose, lungs, stomach, and intestines. Dendritic cells participate in a critical part of the immune response: presenting the prey. Dendritic cells show parts of the killed microbes to the adaptive immune system, so it can coordinate the proper defensive reaction. Because dendritic cells are part of the innate immune system but activate the adaptive immune system, they serve as a bridge between the two different parts of the immune system.

\section{THE END OF THE BATTLE}

Eventually, innate immune cells get help from cells of the adaptive immune system. There is not a fixed point when the innate immune system stops and the adaptive immune system takes over; the two systems communicate with each other all the time. In most cases, the inflammatory reaction stops once the microbe is eliminated from the body by adaptive immune cells and damaged body tissues are repaired. When a splinter is removed from your finger, the area will be red and painful for a while, but eventually your skin will heal. Although inflammation is a critical part of the immune response, it is important that inflammation stops once the invading microbe is gone. If inflammation is not controlled, the immune system is constantly on high alert this can lead to chronic inflammation [4]. Chronic inflammation can cause damage to the body's organs and tissues and may contribute to problems such as asthma and cardiovascular diseases. Thus, the end of the battle is just as important as the start of the battle!

\section{CONCLUSION}

The immune system is a complex network with one goal: to keep you as healthy as possible! The innate immune system is an essential part of the immune system that is activated immediately once an invader tries to enter the body. It protects us by maintaining a fortress around the body and by trapping and killing any dangerous microbes that manage to invade. The innate immune system protects us until the adaptive immune system takes control, finishes the battle, and generates memory of the invader to protect us against future attacks. Since the immune system is so important, we should do what we can to keep it performing optimally. How? Eat healthy foods, drink plenty of 
water, get enough sleep, exercise regularly, and try to avoid too much stress. A healthy immune system means a healthy body!

\section{ACKNOWLEDGMENTS}

The figures were made using Servier Medical Art. This work was supported by a grant from the South-Eastern Norway Regional Health Authority (MCL, 2019058).

\section{REFERENCES}

1. Takeuchi, O., and Akira, S. 2010. Pattern recognition receptors and inflammation. Cell. 140:805-20. doi: 10.1016/j.cell.2010.01.022

2. Medzhitov, R. 2008. Origin and physiological roles of inflammation. Nature. 454:428-35. doi: 10.1038/nature07201

3. Chaplin, D. D. 2010. Overview of the immune response. J Allergy Clin Immunol. 125:S3-23. doi: 10.1016/j.jaci.2009.12.980

4. Schett, G., and Neurath, M. F. 2018. Resolution of chronic inflammatory disease: universal and tissue-specific concepts. Nat Commun.

9:3261. doi: 10.1038/s41467-018-05800-6

SUBMITTED: 22 September 2020; ACCEPTED: 02 September 2021; PUBLISHED ONLINE: 11 October 2021.

EDITED BY: Sagar Chittori, University of British Columbia, Canada

CITATION: Louwe MC and Aukrust P (2021) How the Innate Immune System Fights for Your Health. Front. Young Minds 9:609074. doi: 10.3389/frym.2021.609074

CONFLICT OF INTEREST: The authors declare that the research was conducted in the absence of any commercial or financial relationships that could be construed as a potential conflict of interest.

COPYRIGHT @ 2021 Louwe and Aukrust. This is an open-access article distributed under the terms of the Creative Commons Attribution License (CC BY). The use, distribution or reproduction in other forums is permitted, provided the original author(s) and the copyright owner(s) are credited and that the original publication in this journal is cited, in accordance with accepted academic practice. No use, distribution or reproduction is permitted which does not comply with these terms.

\section{YOUNG REVIEWERS}

\section{AARUSH, AGE: 12}

$\mathrm{Hi}$, I live in the Netherlands. I study math, science and many languages at school. Outside school, I like to play Badminton, and I also play the violin. At home, I mostly spend time playing video games and creative fun games with my sister. 


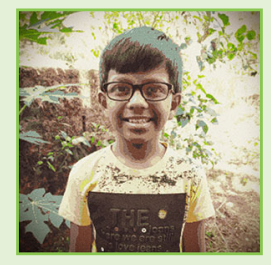

\section{VIBHAV, AGE: 9}

I am Vibhav from India studying in 5th grade. My areas of interest are science, mathematics, and computer engineering. I love to play chess and outdoor games such as cricket and badminton. I enjoy reading story books, solving puzzles especially puzzle-solving exams like Olympiads. I love to play the flute.

\section{AUTHORS}

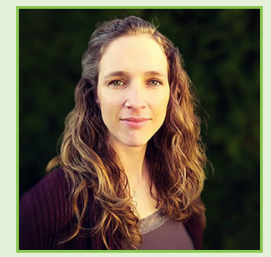

\section{MIEKE C. LOUWE}

I am passionate about the role the innate immune system plays in the development of cardiovascular diseases. I studied this during my Ph.D. in Leiden, the Netherlands, and thereafter I moved to Norway. As a postdoctoral researcher at Oslo University Hospital, I am studying a very specific part of the innate immune system and how tweaking this could help to prevent stroke and heart diseases. In my free time I like to run, play with my children, and bake cakes. *m.c.louwe@ous-research.no

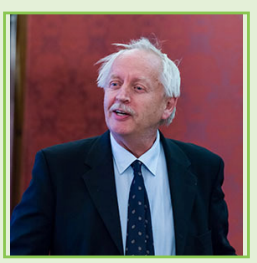

\section{PÅL AUKRUST}

I am a professor at Oslo University Hospital and the University of Oslo, and I study inflammation and mechanisms related to the immune system in cardiovascular disease, immune deficiency, and infections. I work as a doctor in the clinic where I treat patients with severe infections and immunodeficiencies. Since February 2020 I have been heavily occupied by the COVID-19 pandemic, leading the testing of novel drugs in Norway as part of the World Health Organization's Solidarity Study. When I am not at the hospital (unfortunately too seldom), I like to go into the mountains, listen to all kinds of music, read books (particularly crime books), and spend time with my family. 